\title{
INTERTEKSTUALITEIT - ENSIKLOPEDIE EN ARGEOLOGIE: MATTEUS SE VOORSTELLING VAN JESUS AS REDDER
}

Author:

Andries G. van Aarde ${ }^{1}$

Affiliation:

${ }^{1}$ Fakulteit Teologie,

Universiteit van Pretoria,

Suid-Afrika

\section{Correspondence to:}

Andries G. van Aarde

e-mail:

andries.vanaarde@up.ac.

za

\section{Postal address:}

Fakulteit Teologie,

Universiteit van Pretoria,

Lynnwoodweg, 0083,

Hatfield, Suid-Afrika

\section{Keywords:}

Evangelie van Matteus; intertekstualiteit; Jonathan Culler; Gérard Genette; Julia Kristeva; Roland Barthes; J-F. Lyotard; Jesus as saviour

\section{Dates:}

Received: 25 Feb. 2009

Accepted: 16 July 2009

Published: 03 Sept. 2009

How to cite this article:

Van Aarde, A.G., 2009,

'Intertekstualiteit

- ensiklopedie en argeologie: Matteus se voorstelling van Jesus as redder', HTS Teologiese Studies/Theological Studies 65(1), Art. \#156, 10 pages. DOI: 10.4102/hts.v65i1.156

\section{This article is available} at:

http://www.hts.org.za

\section{Nota:}

Hierdie artikel is ' $n$ Afrikaanse verwerking van die artikel wat gepubliseer is in Hatina, T.R. (red.), 2008, 'Biblical interpretation in early Christian gospels', in Volume 2: The Gospel of Matthew, pp. 163-182, T \& T Clark International, Londen. (A Continuum imprint.)

(C) 2009. The Authors. Licensee: OpenJournals Publishing. This work is licensed under the Creative Commons Attribution License.

\section{ABSTRACT}

Intertextuality - encyclopedia and archaeology: Matthew's presentation of Jesus as saviour This article aims to explore and to apply what Gérard Genette refers to as kinds of transtextual relationships and what Ulrich Luz, in his application of these insights to the Gospel of Matthew, calls the encyclopaedia of the author or the original readers. The former enterprise entails exploring intertextuality at the synchronic level and the latter examines intertextuality at the diachronic level. The first pertains to Matthew's pretexts. The second enterprise entails an engagement with pragmatical aspects such as the context of the intended readers and the sedimentation of prior texts designated by the notion intertextuality. In this article the pragmatical aspects concern a discussion of the manner in which the first readers could be addressed by the pretexts of the use of the word sōzō ('to save'). It consists of three parts. The first represents a concise reflection on criteria and methods relevant to an investigation of intertextuality. The second exemplifies the 'encyclopedia' of Matthew's intertextuality, that is 'intertext', 'paratext', 'hypertext', 'hypotext', 'architext', and 'metatext'. The third part discusses the pretexts of the various occurrences of the word sōzō in Matthew.

\section{INLEIDING}

Wanneer ' $n$ mens die 'interteks' verken wat die konteks gevorm het waarin die term sōzō in die Evangelie van Matteus (1:21c; 8:25; 9:20-22; 14:24; 16:25; 19:23; 24:14; 27:39-40, 41-43, 49) gebruik is, kom Matteus se voorstelling van Jesus as 'geneser-messias' duidelik na vore.

So ' $n$ ondersoek behoort egter bedag te wees dat die begrip 'intertekstualiteit' nie maar bloot 'n nuwe etiket is vir wat voorheen as 'histories-kritiese benaderings' bekend gestaan het nie. Sodanige historiese metodes is ingespan om tekste en hulle intra-, inter- en ekstra-tekstuele verhoudings te ondersoek met die doel om die bedoeling van die historiese outeur van die betrokke dokument te identifiseer. Die klem was derhalwe geplaas op 'n diachroniese analise. 'n Outeur se gebruik van Gattungen en tekstipes (genres), bronne, tradisies, motiewe en die oorleweringsgeskiedenis van motiewe, en die sosiale lokaliteite daarvan, is nagegaan. Hierdie gegewens word waargeneem in die redaksionele en komposisionele tendense van die oorspronklike outeur wat ingebed was in ' $n$ bepaalde sosiale omgewing in die antieke tyd.

In die verlede het dit ook gebeur dat eksegete misleidend - dikwels onbewustelik - ou metodologiese benaderings en insigte opnuut gebruik en die indruk van innovasie skep, terwyl dit verbloem is in die woordeskat van 'n sonaamde postmoderne tesourus. Dit was die geval selfs toe eksegete na bewering hulle klem van 'n diachroniese analise van 'n teks se geskiedenis verskuif het na 'n sinchroniese verduideliking van die immanente struktuur van die teks (soos byvoorbeeld ' $n$ verhaal se narratologiese komponente). In die 1970's byvoorbeeld, is terme soos komposisie-kritiek en redaksie-kritiek in sommige literêr-kritiese studies as 'narratiewe kritiek' hernoem (onder andere die Matteus-studies van Jack D. Kingsbury in 1974). Later het sekere eksegete, soos Norman R. Petersen (1980a:185-186; vgl ook Petersen 1980b), en Kingsbury (1986:1-2) self, begin om 'n onderskeid te tref tussen literêr-kritiese en histories-kritiese benaderings. So byvoorbeeld sê Kingsbury (1986:1) dat 'literêre kritiek onafhanklik van ' $n$ histories-biografiese, vorm-kritiese en redaksioneel-kritiese benaderings tot Matteus gesien moet word' (my parafrase in Afrikaans).

Dit wil eweneens voorkom of 'intertekstualiteit' binne die kring van die Bybelwetenkap bloot sinoniem vir tradisiekritiek en vormkritiek geword het. In die verband behoort ag geslaan te word daarop dat literêre kritici dit vir eksegete opmerksaam maak dat begrippe verwarrend gebruik kan word. Byvoorbeeld, in sy essay 'Presupposition and intertextuality', meld Jonathan Culler ([1981] 2001:103) dat die studie van intertekstualiteit nie dieselfde is as ' $\mathrm{n}$ ondersoek van bronne en invloede soos wat tradisioneel begryp is nie. Intertekstualiteit se net is wyer gespan, sodat ook anonieme diskursiewe konvensies en literêre kodes ingesluit word. Hierdie gebruike en kodes se oorsprong kan weliswaar in die loop van tyd verlore gegaan het, maar dit bly die dinamiek wat daartoe gelei het dat ander tekste later sekere kenmerke bevat wat die spore van 'n intertekstuele geskiedenis vertoon.

Met metodes vanuit die histories-kritiese paradigma was eksegete geneig om op vrae aangaande die evolusionêre wording van 'n dokument te fokus. Hulle het nie soseer in die samestelling, dit wil sê die komposisie, van die literêre eindproduk belang gestel nie. Selfs as 'n histories-kritiese eksegeet die struktuur en samestelling van 'n dokument ondersoek het, het sodanige eksegese gewoonlik uit vrae bestaan aangaande die redaksionele verwerking of redigering wat tot die skepping van 'n 'nuwe' dokument aanleiding gegee het. Sodanige eksegese was geneig om op dokumente se geskiedenis, meer as op enigiets anders, te konsentreer. 'n Histories-kritiese ondersoek het tipies gefokus op vrae wat daarop gemik was om vas te stel deur wie 'n dokument geskryf is, op wie dit gerig was en waar en wanneer dit geskryf is. Sodanige ondersoek veronderstel dat insig in die historiese proses van die daarstelling van 'n dokument die eksegeet van hulp kan wees om antwoorde te vind op vrae met betrekking tot oorsaak en gevolg. Die aanname sou dan wees dat die vasstelling van hierdie evolusie veronderstel 
dat historiografie dit moontlik maak om die betekenis van die dokument te bepaal.

Die doel van hierdie artikel is om twee 'beperkte benaderings tot intertekstualiteit' op sekere frases (ofte wel 'tekste') in die Evangelie van Matteus toe te pas, soos Jonathan Culler (2001:118) sy studie van intertekstualiteit bestempel (my ver-Afrikaansing van die oorspronklike). Die een benadering het te make met spesifieke vooronderstellings identifiseerbaar in 'n gegewe teks wat op die aanwesigheid van 'n pre-teks in die bepaalde teks dui. Met 'pre-teks' word hier 'n soort 'inter-tekstuele ruimte' bedoel wat lesers/interpreteerders kan betree en raakpunte, of nie, met ander werklik bestaande tekste moontlik kan hê. Culler verwys hierna as 'pragmatic presuppositions'. So gesien, kan die Evangelie van Matteus as die 'gegewe teks' gereken word, of bepaalde frases/tekste daarin.

Die 'tweede onderneming', aldus Culler (2001:118), het te doen met die verduideliking van hoe tekste self vooronderstellings by die eksegeet/leser/interpreteerder oproep en gevolglik pre-tekste skep. Volgens Culler behels die eersgenoemde onderneming dat intertekstualiteit op sinchroniese vlak ontgin word en laasgenoemde onderneming behels die ondersoek na intertekstualiteit op die diachroniese vlak. Die tweede onderneming fokus die ondersoek op die te gekreëerde vooronderstellings wat agter 'n teks geleë kan wees. Sodanige vooronderstellings wat so by die eksegeet opgereoep word, het nie net te doen met sekere konvensionele gebruike wat die retoriek van die tekstuele diskoers kon beïnvloed nie, maar ook met 'sedimente' van vroeëre tekste wat in die gegewe teks aanwesig is. Beide die vooronderstellings en die retoriese gebruike, asook die spore van vroeëre tekste, word met behulp van die begrip 'intertertekstualiteit op pragmatiese vlak' aangedui (kyk Culler 2001:118).

In hierdie essay het die 'pragmatiese vooronderstellings' (pragmatical presuppositions) te make met 'n bespreking van dít waarna Gérard Genette (1982:8) verwys as types de relations transtextuelles (transtekstuele verhoudingstipes) en waarna Ulrich Luz (2003) ${ }^{1}$ verwys as die "Enzyklopädie" des Autors oder Erstlesers' (ensiklopedie van die skrywer of die oorspronklike leser). Die sinchroniese dimensie behels die 'intertekstuele ruimte' waarin bepaalde 'okkupeerders' (in hierdie geval Matteus se bedoelde lesers) deur die 'pre-tekste' van die woord sōzō aangespreek kon word.

Die artikel bestaan uit drie dele. Die eerste bevat 'n beknopte besinning oor die kriteria en metodes wat van toepassing is by die ondersoek van intertekstualiteit. Die tweede tipeer die 'ensiklopedie' van Matteus se intertekstualiteit; en die derde is 'n bespreking van die 'pre-tekste' van die onderskeie gevalle waar die woord sōzō in Matteus voorkom.

\section{KRITERIA EN METODES}

Wat 'n ondersoek na Matteus se 'intertekste', die 'tekste' agter die gebruik van die woord sōzō betref, moet 'n mens in ag neem dat 'criteria, no matter how good', volgens Crossan (1998:143, 145), ... do not constitute a method unless they are organized on some theoretical basis into some operational system that can be used by anyone.' Vir die doeleindes van hierdie artikel is dit dus nodig dat daar kortliks oor die begrip 'intertekstualiteit' besin word.

Intertekstualiteit beskou die totstandbringing van 'n teks, asook die komposisie en boodskap daarvan, vanuit 'n radikaal ander hoek as wat historiese kritiek dit beskou. Die volgende précis deur Jonathan Culler (2001:103) gee iets van die nuutheid van hierdie nuwe benadering weer: 'Intertextuality thus becomes less a name for a work's relation to particular prior texts than a designation

1.Luz se SNTS-voordrag (2003), in Duits gelewer, is in Engels verwerk en in 2004 in Harvard Theological Review 97(2), 119-137, gepubliseer. My bespreking van Luz is op die oorspronklike Duitse voordrag gebaseer en die vertaling van Duitse frases in Afrikaans is deur myself gedoen. Skrywer was die voorsitter van die SNTS seminaar in Bonn toe Luz sy voordrag gelewer het. of its participation in the discursive space of culture.' Gesien vanuit hierdie perspektief, is 'n teks nie 'n konfigurasie van taalsimbole as sodanig nie, maar eerder 'n komplekse taalsimbool binne 'n konstellasie van tekste.

Taal is essensieel 'n produk van sosiologiese interaksie. Die sosiale konteks kan beskou word as die meganisme wat tekste genereer. Elke teks is 'n refleksie van die sosiale konteks waaruit dit gekommunikeer word. Danow haal 'n opmerking uit die werk deur Uspenski (1973) en Lotman (1974) aan wat belangrike intertekstuele implikasies inhou:

A text can only be understood if it is compared extensively with the culture, or more precisely with the behavior of the people contemporary with it; and their behavior can likewise only be made sense of if it is juxtaposed with a large number of texts.

(Danow 1987:352)

Sosiale konteks is egter ' $\mathrm{n}$ indirekte, eerder as 'n direkte 'meganisme' agter die generasie van tekste. Dit is mense wat direk verantwoordelik is vir die daarstelling van tekste.

Daarmee word nie geïmpliseer dat historiese kritiek nie 'n bydrae tot 'n begrip van die 'intertekstualiteit' van 'n teks (soos dié van Matteus) gelewer het nie. Voorts beteken dit ook nie dat historiese kritiek se bemoeienis met bronne wat die daarstelling van 'n teks voorafgaan, irrelevant is wanneer Matteus naas ander tekste gestel word nie. Historiese kritiek behels egter nie die eksegetiese paradigma van ' $n$ intertekstuele benadering nie. Dit is om dié rede dat die studie van Matteus se intertekstualiteit erkenning verg van 'n verwysingsraamwerk waarmee teoloë deesdae die konsep benader. Dit kom daarop neer dat nuwe denke aan die dag gelê word sonder dat vorige denke buite rekening gelaat word.

Luz (2003) byvoorbeeld voer aan dat hy in sy eksegetiese, historiese en hermeneutiese werk prinsipieel (grundsätzlich) belangstel in intertekstualiteit as 'n model ingevolge waarvan 'n outeur se ideologie en tegniek - oftewel die Art und Weise, soos hy daarna verwys - by die gebruik van 'intertekste' ontbloot kan word. Hy is van oortuiging dat daar maniere bestaan hoe om intertekste metodies te identifiseer en te ondersoek, sodat die proses op 'n vakkundige en gekontrolleerde wyse plaasvind. Ook op die vlak van resepsie is dit die taak van 'n hermeneut om die verskillende wyses waarop 'n teks ontvang word, binne die beperkings van die teks self te evalueer. Dit kom derhalwe daarop neer of die geïdentifiseerde interteks werklik met die outeur se bedoeling in verband gebring kan word en of die metode wat gebruik is in die identifikasie van hierdie interteks korrek toegepas is.

Dit is daarom belangrik om kennis te neem van eerstens Stefan Alkier (2005:2) se onderskeid tussen 'n 'beperkte' en 'onbeperkte' opvatting van intertekstualiteit en andersyds van die onderskeid wat hy tussen die fenomeen van teksdaarstelling en die praktyk van die ontvangs daarvan tref. In eersgenoemde onderskeid is die term 'interteks' sinoniem met kultuur in die algemeen teenoor 'interteks' as 'n konkrete teks. Die tweede kategorie het te make met 'n onderskeid tussen intertekstualiteit op tekstuele vlak, hetsy op die vlak van outeursbedoeling, of op die vlak van ontvangs deur die leser. Wat laasgenoemde betref, sê Luz dat hy as historikus en hermeneut verkies om in die eksegese te fokus op die Textebene (tekstuele vlak), dit wil sê 'die vlak van outeursbedoeling', Volgens hom behoort die Leserebene (leservlak), dit wil sê 'die vlak van leserontvangs', tot die konkrete teks gereduseer te word.

Alkier, wat op die werk van die teoretici Charles Sanders Peirce (1934; vgl Liszka 1996:91-2) en Umberto Eco (1984:14) voortbou, het die konsep 'teks' vanuit 'n semiotiese perspektief gedefinieer deur 'n onderskeid te tref tussen sintagmatiek, semantiek en pragmatiek. In die sintagmatiek word tekste beskou as 'tekens' wat aan ander 'tekens' verwant is. In die semantiek word tekste beskou as 'tekens' wat ander 'beduidende' tekens aandui. 
In die pragmatiek word tekste gesien as 'tekens' wat in verband met gebruikers gebring word. ' $n$ Ondersoek van hierdie verhoudings kan vanuit ' $\mathrm{n}$ teks-interne of ' $\mathrm{n}$ teks-eksterne perspektief gedoen word en beide hierdie sienswyses verg twee stappe by 'n semiotiese lesing. Die eerste perspektief behels ' $n$ intratekstuele lesing wat ' $n$ gegewe teks as ' $n$ wêreld in sigself beskou, dit wil sê ' $n$ 'universum' (ofte wel 'diskoers') wat uit 'woordstrukure' en 'ideologiese strukture' bestaan. Volgens Eco (1984), het die tweede perspektief betrekking op 'n teks se 'ensiklopedie' wat kennis aangaande die kulturele kodes (soos byvoorbeeld politieke, geografiese en sosiale kodes) aan die leser verskaf om die teks te interpreteer deur so genoemde 'onbeskrewe dele' (in Duits: Leerstelle) - ofte wel 'gapings' - van ' $n$ bepaalde teks in te vul.

$\mathrm{Na}$ aanleiding van die insigte van Julia Kristeva (1969) en Roland Barthes (1985; vgl Hillenaar 1982:53) het Luz (2003) die volgende opmerking gemaak: 'Intertextualität ist also letztlich nicht anders als die textliche Gestalt, in der sich Kultur, Geschichte und Gesellschaft in Texte eingravieren' ('intertekstualiteit is eintlik niks anders nie as die tekstuele vorm waarin kulture, geskiedenis en die samelewing hulleself op tekste ingraveer het' $^{\prime}$ my vertaling). Hierdie aanhaling maak dit duidelik dat die uitdrukking textliche Gestalt ('tekstuele gestalte') op 'tekstuur' dui, dit wil sê 'n teks gevul met kulturele, historiese en sosiale konvensionele kodes. Hierdie drie begrippe, te wete kultuur, geskiedenis en gemeenskap, bring mee dat die wêreld van óf die outeur óf die leser bewustelik of onbewustelik op ' $n$ diachroniese of sinchroniese vlak eggo wanneer outeur of leser met die teks in interaksie is.

Intertekste op die eerste vlak, dit wil sê bewuste eggo's, sluit in die bronne van die teks wat die herinnerings ontsluit van beide die outeur en die bedoelde lesers, wat in die teks se bronne ingebed kan wees. Dit gebeur omdat daar figure met ' $n$ besondere geskiedenis is van wie se lewensverhale in tekste - soms onbewustelik, soms onbewustelik - die herinnerings vorm wat as modelle van identiteit en gedrag vir outeur of leser dien. So 'n interaksie vorm die 'intertekste' op die eerste vlak. Intertekste op die tweede vlak, dit wil sê onbewuste eggo's, het betrekking op die kodes wat teoreties-estetici in resepsieteorieë uitgelig het.

Hierdie artikel fokus op die so genoemde 'bewuste eggo's'. So ' $n$ intertekstuele leesstrategie verg dat die'herinnerings' wat in Matteus se teks opgesluit is, en dié van Matteus se bedoelde lesers, deur middel van 'teks-interne tekens' (waarna vroeër in die artikel verwys is as die teks se ensiklopedie) te ontgin. Om dit te kan doen behoort kodes verskaf te word om Matteus se evangelie in sy kulturele konteks te lees. Die bedoeling van so 'n lesing is om die 'onbeskrewe dele', dit wil sê die 'leë ruimtes', in te vul met die doel dat ander lesers van my interpretasie die gebruik van die woord sōzō kan volg. ' $\mathrm{n}$ Verdere teoretiese besinning is egter nodig om te begryp wat met die term 'ensiklopedie' bedoel word.

\section{DIE 'ENSIKLOPEDIE' VAN MATTEUS}

\section{Begripsverheldering}

Om die eggo's van die wêreld waarbinne ' $n$ teks betekenis het, te herken, kom in ' $n$ sekere sin daarop neer dat die eksegeet die outeur van die teks en die eerste lesers daarvan 'dekontekstualiseer'. Dit kan gedoen word deur aan die een kant te probeer om die outeur se kommunikatiewe bedoeling met die teks te rekonstrueer en aan die ander kant agter hierdie teks in te kom, dit wil sê die outeur van die teks self te 'skei', met ander woorde te 'dekontekstualiseer'. Laasgenoemde word bereik deur ' $n$ onderskeid te tref tussen die 'stemme van die bronne' wat in die teks deur die outeur aangewend is, en die baie spesifieke bedoeling wat die skrywer met die bepaalde teks kon gehad het. Dit is hierdie 'stemme' wat betrekking het op die 'ensiklopedie' van die teks.
In hierdie artikel word die fokus alleen gelê op die vlak van die Textebene ('teksvlak'), dit wil sê op Matteus as outeur en die teks se bedoelde geadresseerdes, die Erstleser (die eerste of oorspronklike lesers). Hierdie gekose fokus beteken dat ' $n$ sinchroniese ondersoek na Matteus se taalgebruik nie in hierdie artikel ontgin word nie Die Leserebene kry dus nie aandag nie, met ander woorde ' $n$ ondersoek na die teks se ontvangers of lesers deur die geskiedenis tot op hede.

Om hierdie doel in die artikel te bereik is dit nodig om die term Textarchäologie ('teksargeologie') te verduidelik. Hierdie term word gebruik om te verwys na ' $n$ toeligting van die tradisie- en die oorleweringsgeskiedenis van die Evangelie van Matteus. So ' $n$ studie neem die geskiedenis van die oorspronge van die teks in ag. Die funksie daarvan is om die kommunikasiestrategieë in die teks te definieer. Indien die fokus op die teks se ontvangers en hedendaagse lesers sou val, sou die hermeneutiese aanname wees dat die teks nie ' $n$ presiese betekenis het nie, maar hoogstens moontlike betekenisse. Omdat die artikel nie spesifiek op leserestetiek toegespits is nie, moet aanvaar word dat die toeligting van Matteus se kommunikasiestrategieë wat in hierdie artikel aan die orde kom, tekens van my subjektiewe (re)konstruksie van die teks sal toon.

Die studie van die 'argeologie van die teks' behels ' $\mathrm{n}$ ondersoek na 'sekondêre tekste'. Genette (1982:7-16) het verskillende tipes 'sekondêre tekste' geïdentifiseer. By die oorweging van Matteus se 'intertekstuele' perspektief kan dit van betekenis wees om die bedoeling van die evangelis as outeur as ' $n$ spesifieke intertekstuele kategorie in ag te neem. Een van die maniere hoe dit gedoen kan word, het ons reeds gesien, is om Matteus se oogmerk te skei van die 'stemme' van die bronne waarna Matteus as outeur verwys. Genette (1982:7-16) kategoriseer hierdie 'stemme' as (1) die interteks, (2) die parateks, (3) die hiperteks, (4) die hipoteks, (5) die argeteks en (6) die metateks.

In Luz (2003) se toepassing van hierdie kategorieë op die Evangelie van Matteus, verwys die term 'interteks' na die aanwesigheid van ' $n$ ander teks in ' $n$ bepaalde teks (byvoorbeeld aanhalings, sinspelings en kopiëring wat in vandag se terme 'plagiaat' genoem sal word).

Addisioneel tot interteks moet ook parateks in berekening gebring word. Dit dui op die voorkoms van 'tekste' in die teks waarvan die funksie meer 'langs' (para) as 'in' die teks is, soos byvoorbeeld voorwoorde, voetnote, kantaantekeninge en selfs die titel binne 'n ander teks.

Derdens is daar die hiperteks wat verwys na die tipe teks wat geskep is na aanleiding van ' $\mathrm{n}$ 'basisteks', die sogenaamde hipoteks, wat egter nóg in die hipoteks as die 'eerste' teks (soos 'n 'interteks') opgeneem word, nóg as ' $\mathrm{n}$ kommentaar op die 'eerste' teks (soos ' $\mathrm{n}$ 'metateks') dien. So byvoorbeeld vorm Virgilius se Aeneïs ' $n$ 'hiperteks' tot die Odysseus as 'hipoteks'.

'n Argeteks verwys na 'n algemene tekstipe wat as model vir ander tekste dien, dit wil sê, dit is 'n Gattung (genre).

Ten slotte is daar die sogenaamde metateks wat ' $\mathrm{n}$ teks soos byvoorbeeld 'n kommentaar is wat van die Grundtext ('hipoteks') te onderskei is.

\section{Matteus se sekondêre tekste Metateks}

Wat die kategorie wat heel laaste genoem is, betref, naamlik die metateks, word vakkundig algemeen aanvaar dat die Markustradisie as raamwerk vir Matteus gedien het met die toevoeging van $\mathrm{Q}-$ materiaal. Na aanleiding van hierdie aanname ontstaan die vraag of die Evangelie van Markus as Matteus se hipoteks (Grundtext) gedien het en of Matteus as ' $n$ 'kommentaar' op Markus, of as hiperteks daartoe gelees moet word. 
Indien ' $\mathrm{n}$ mens die Evangelie van Matteus as ' $\mathrm{n}$ hiperteks beskou, sou dit 'n geringer mate van onafhanklikheid van Markus impliseer-'nopsie wat die bestaande insigte in Matteusnavorsing nie onderskryf nie. Dit is makliker om die eerste opsie te verdedig. Hierdie opsie impliseer dat die Evangelie van Matteus as geheel ' $\mathrm{n}$ metateks is, wat in wese te onderskei is van Markus as hipoteks en dat $\mathrm{Q}$ ' $\mathrm{n}$ interteks is wat in Matteus (en Lukas) as dié se hipoteks opgeneem is.

Indien 'n mens Matteus as 'n metateks (ditwilsêas' $n$ 'kommentaar' op Markus beskou), kan Matteus se inhoud as kommentaar in die vorm van 'n onafhanklike narratief beskou word. Hierdie 'kommentaar' is gebaseer op 'n différance tussen Matteus en Markus ten opsigte van die narratiewe gesigspunt van waaruit die dissipels in verhouding met Jesus as die Geneser-Messias geteken word. Hierdie opsie word bevestig deur te let op hoe die verteller se sienswyse met betrekking tot die interaksie tussen Jesus en die dissipels aan die een kant en tussen die dissipels en die skare aan die ander kant in die plot van Matteus as 'n storie funksioneer (kyk Van Aarde 2007:416-436).

Gesien vanuit die perspektief van Matteus se gebruik van $Q$, is Matteus dus tegelyk hipoteks en metateks. As 'n ander teks wat Markus vervang, skep Matteus 'n analogie tussen Jesus se opdrag en dié van die dissipels aan die 'menigtes'. Beide opdragte verskil duidelik van dié wat in Markus uitgebeeld word. In hierdie sin dien Matteus as 'n spesifieke tipe 'kommentaar' op (dit wil sê 'n metateks tot) Markus. Laat my my uitleg van Matteus se interaksie tussen Jesus, die dissipels en die menigtes verduidelik.

In die Evangelie van Markus staan Jesus se kruisdood sentraal. Nie alleen is Jesus in konflik met die antagoniste, soos byvoorbeeld die élite van die Israelse volk (insluitende rabbi's onder die Fariseërs en priesterhoofde onder die Sadduseërs) nie, maar ook met die Israelse menigte, ofte wel 'skare' (Mark 4:1-2). Onder laasgenoemde sou 'n mens verwag, sal 'n mens Jesus se 'vriende' aantref asook sy familie (Mark 3:20-21, 31-35) en mede-dorpenaars (Mark 6:1-5). Daar word egter regdeur Markus verslag gedoen oor die vervreemding wat tot Jesus se lyding aanleiding gee het en uiteindelik sy dood aan die kruis (Mark 15:25-41). Markus beklemtoon dat Petrus (Mark 8:29-30), die Twaalf (Mark 9:33) en die seuns van Sebedeus (Jakobus en Johannes) (Mark 10:35-45) God se bedoeling nie verstaan nie. Hierteenoor vertel die Evangelie van Matteus dat God se wil verstaan is, hoewel dit nie noodwendig uitgevoer is nie. In sy kommentaar op Markus, verander Matteus - om hierdie boodskap oor te dra - die rolle van beide die dissipels en die menigte. In Matteus vaar die dissipels daarom beter as in Markus. Hulle weet wie Jesus is, maar ervaar probleme om God se wil na te kom soos wat Jesus dit doen. In die storie het die menigte ' $n$ indirekte rol. Die dissipels se interaksie met die menigte illustreer of die dissipels wel Jesus se boodskap van God se liefde vir alle mense kan betoon, soos Jesus dit gedoen het. Volgens Matteus is die dissipels veronderstel om Jesus na te doen, maar hulle toon 'n onvermoë en slaag nie werklik daarin nie.

Alhoewel Matteus teen die leerstellings van die Fariseërs en Sadduseërs maan (Matt 16:6), is hy nie 'n voorstander van 'n totale breuk met die gebruike van die Tweede Tempel nie (Matt 17:24-27). Sou hy Markus net so oorgeneem het (kyk bv Mark 7:14-23; 10:1-12) - dit wil sê deur Markus as interteks te reken en nie as hipoteks nie - sou dit daarop neergekom het dat hy 'n breuk met die Israelse kultuur (soos byvoorbeeld in Lev 11 en Deut 14 en 24:1, 3 weerspieël) voorstaan.

\section{Argeteks}

Matteus se tekstuur is verteenwoordigend van die genre (argeteks) van 'n diskursief-biografiese evangelietipe en derhalwe is die narratiewe en argumentatiewe struktuur van hierdie Evangelie van belang. Markus as Matteus se hipoteks is verteenwoordigend van die so genoemde biografiese evangelietipe. Die Evangelies van Tomas en $\mathrm{Q}$ is 'spreuke-' evangelies en die Protevangelium van Jakobus is 'n diskursiewe evangelie. Die Epistula Apostolorum en die Handelinge van Johannes is, soos Matteus, voorbeelde van die diskursief-biografiese evangelietipe (kyk Crossan 1998:31-40).

Begrip van hierdie argeteks hou belangrike heuristiese gevolge in vir die ontrafeling van Matteus se kommunikasiestrategieë. Hierdie strategieë word in sy tekstuur so ingewerk dat dit afwisselend uit diskoers- en biografiese materiaal bestaan. Die vyf diskoerse van Jesus (Matt 4:23-7:29; 9:36-11:1; 13:1-52; 18:1-19:1; 23:1-25:46) bevat hoofsaaklik materiaal uit $\mathrm{Q}$ as 'n interteks. Hierdie vyfvoudige verdeling is kenmerkend van die konsentriese kruiskomposisie van Matteus as 'n hipoteks in die lig van die formule in Matteus 7:28-29; 11:1; 13:53; 19:1; 26:1: 'En toe Jesus hierdie woorde klaar geuiter het ...'). Hierdie konsentriese kruisstruktuur is gebaseer op 'n ander formule van Matteus waarvolgens Matteus in drie hoofdele verdeel word (Matt 1:1-4:16; Matt 4:17-16:20 en Matt 16:21-28:20), soos aangedui deur ' $n$ tipiese formule eie aan Matteus: 'Van toe af het Jesus begin om ...' (Matt 4:17; 16:21).

Die vyf redes (Matt 4:23-7:29; 9:36-11:1; 13:1-52; 18:1-19:1; 23:1-25:46) behoort daarom in samehang met die narratiewe diskoerse (Matt 1:1-4:22; 8:1-9:35; 11:2-12:50; 13:53-17:27; 19:2-22:46; 26:1-28:20) - wat daarnaas en daartussenin verskyn - beskou te word. Hierdie kombinasie skep die analogie tussen Jesus se sending en dié van die dissipels. Elke narratiewe diskoers sluit op 'n assosiatiewe wyse aan by die rede wat daarop volg en wat die spiraal na die volgende narratiewe diskoers voortsit en waaruit die integrasie van Jesus se opdrag en dié van die dissipels voortspruit. Beide die dissipels (Matt 5:1; 9:37; 10:1; 13:10; 18:1; 23:1) en die Israelse menigte (Matt 4:23-51b; 9:35 e $\mathrm{v} ; 13: 2 \mathrm{e} \mathrm{v} ; 18: 2 ; 23: 1)$ is aanwesig by die aanvang van elkeen van Jesus se toesprake. Hierdie vyf toesprake is op die dissipels gerig en is van besondere relevansie vir die verhouding tussen die dissipels en die Israelse menigte.

\section{Hiperteks as 'n kommunikasiestrategie op 'n konkrete vlak}

Hierbo het ek daarop gewys dat die begrip hiperteks verwys na 'n tipe teks wat geskep is deur op 'n 'basisteks' staat te maak. In die geval van Matteus is die Evangelie van Markus die basisteks. Soos egter reeds opgemerk, het Matteus as 'n onafhanklike narratief met 'n outonome sienswyse ontwikkel. 'n Oorweging van Matteus as 'n hiperteks behels dus 'n besinning van die dominante kommunikasiestrategie wat in Matteus se storie gebruik is deur dit noukeurig met die strategie in Markus se storie te vergelyk.

Volgens my interpretasie is Matteus se narratief gefokus op God wat Jesus gestuur het om Israel te red, soos wat 'n Josua-figuur uit Egipte as Moses se opvolger gekom het. Dit wil sê, die Josua-storie dien inderdaad as Matteus se hiperteks. Dit beteken egter nie dat die boek van Josua as 'n bepaalde teks in die Hebreeuse Bybel of in enige ander teks waarin die Josua-figuur van die Ou Testament die protagonis is, as eksplisiete interteks vir die outeur wat vir die Evangelie van Matteus verantwoordelik was, gedien het nie.

Vanuit 'n ander perspektief gesien, verwys die term hiperteks na iets soortgelyk as waarna J-F. Lyotard (1989:131) as 'n 'groot

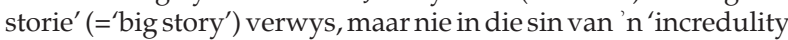
toward metanarratives' ( dit wil sê 'grand narratives") soos wat Lyotard (1984:xxiv) (vgl Thiselton 2006:670-671) dit in 'n postmoderne konteks bestempel nie. Indien die Josua-storie in die Hebreeuse Bybel die 'big story' sou wees waarop die outeur van Matteus staat gemaak het, sou sý Jesus-storie, soos Lyotard dit sien, 'n 'little story' wees. Gesien vanuit die perspektief van so 'n postmoderne argument, handel Matteus se 'little story' oor die man Josua aan wie Maria in die Judese stad van Bethlehem geboorte geskenk het. 
Gina Hens-Piazza (2000:164) haal Lyotard (1989:131) aan wat hom teoreties soos volg oor die begrip 'little story' uitdruk: 'You make up little stories. Or even segments of little stories, listen to them, transmit them, and act them out when the time is right.' Hens-Piazza wil dan weet waarom die keuse op die term 'little story' geval het. Die antwoord daarop vind sy in Lyotard (1989:132-133, 134) se verduideliking: 'Because they are short, because they are not extracts from some great history, and because they are difficult to fit into any great history ... History consists of a swarm of narratives, narratives that are passed on, made up, listened to and acted out; the people do not exist as a subject ...' (my beklemtoning).

In hierdie geval bedoel Lyotard met die term geskiedenis die geskiedenis van die 'dominante Westerse diskoers' (reigning Western discourse). Ten tye van die aanvang van die Christelike jaartelling was die verwagting van 'n apokaliptiese verlosser wat God se volk op 'n Josua-Moses wyse sou bevry, die 'big story' in Israel se geskiedenis. Die inwoners van Palestina was nie as 'menswaardige subjekte' in die groot narratief van die Pax Romana geag nie. Hulle was uitgebuit en van hulle land af gedwing - en gedagtig aan hoe hulle eie leiers (onder beide die Sadduseërs as die Fariseërs) met invloedryke indiwidue wie se mag deur Rome afgedwing is, meegewerk het, was hulle metafores gesien soos 'verlore skape sonder ' $n$ herder'. Aangesien hulle 'n volk was wat nie as 'menswaardige subjek' bestaan het nie, sou hulle stemme en stories nie gehoor gewees het nie, was dit nie vir 'n outeur, wat in sy eie woorde in Matteus 13:52, soos 'n 'skrifgeleerde wat 'n leerling word in die koninkryk van die hemel' en sy 'klein storie' in die lig van Israel se geskiedenis vertel het nie. Soos Lyotard (1989:134) dit sien, is dit 'a mass of thousands of little stories that are [at] once futile and serious, that are sometimes attracted together to form bigger stories, and which sometimes disintegrate into drifting elements.'

Matteus se narratief is dus nie 'n 'klein storie' in die sin dat dit die Josua-storie as 'n 'metanarratief' dekonstrueer nie. 'n Ander tipe geskiedenis het die metanarratief in Matteus se tyd gevorm. Matteus se narratief oor die 'nuut-gebore Josua' (=Jesus) dekonstrueer die koalisie tussen eerste-eeuse Romeinse imperialisme en die Fariseïsme as die groot 'metanarratief' (grand narrative) van daardie tyd. In sodanige konteks funksioneer die Josua-Moses storie as 'n hiperteks. Dit het die sosiaal-kulturele konteks gevorm waarbinne die eerste-eeuse Farisese 'rabbinaat' (wat toe maar nog net in kinderskoene gestaan het) vanuit die ruimtes van sinagoges op Galilese en Siriese grondgebied begin het om met die Romeinse Ryk mee te werk.

Teen die agtergrond hiervan en te midde van 'n sodanige grand narrative, handel Matteus se 'kontranarratief' oor 'n ander JosuaMoses - een wat uit Bethlehem, en nie uit die 'koninklike stad' Jerusalem (Matt 2:4-6) kom nie. So beskou, vorm Matteus se storie 'n ander little story waarin die Josua-Moses metanarratief die hiperteks vorm. Sodanige hiperteks kom in talle tekste voor. Hierdie tekste kan as 'intertekste' vir mekaar beskou word, maar dit beteken nie dat die een doelbewus in die ander opgeneem word of dat die een op die ander sinspeel nie. Ander 'intertekstuele' motiewe wat ook kulturele beelde of idees in gemeen het, kom ook voor sonder dat dit bewustelik uit 'n spesifieke teks aangehaal is of daarop gesinspeel word. Hulle kom voor in ander dokumente uit dieselfde tyd wat wel tekstueel verwant is. In Matteus is die Josef-tradisie 'n sprekende voorbeeld. ${ }^{2}$

2.Dit kom onder andere voor in die Testamente van die Twaalf Patriarge (bv T Benja$\min 4: 2 ; 4: 4 d$; $T$ Sebulon 6:5; 7:3f; $T$ Gad 2:1; 2:3-4; 4:1-2; 6:3-4, 7 (vgl Hollander 1981; Sklar 1996; Zerbe 1993; Argyle 1951-2:256-258) en in die roman Josef en Asenat (o a JosAs [Ph] 15:7-8; JosAs 17:9 [B]). Matteus maak van hierdie tradisie gebruik in sy uitbeelding van Maria se eggenoot en ook dié van Jesus (kyk Van Aarde 2000:1-21). Alhoewel Asenat se maagdelikheid nie in die Genesis-weergawe vermeld word nie (Gen 41:45, 50), was beide die ard van Josef se huwelik met Asenat en haar maagdelikheid welbekend as algemene literêre motiewe in die met Asenat en har 9), 'n paralle met Josef en Asenat, na hulle 'most distinguished marriage' en na Asenat se maagdelikheid (vgl Chesnutt 1996:286). Dit is derhalwe van belang om daarvan
Matteus se voorstelling van die Josua-motief word omskep in 'n storie wat oor 'n keuse van leierskap handel. Hierdie keuse word gekonkretiseer in die uitoefening van twee keuses onderskeidelik: óf die mense gee erkenning aan Iēsous ('Josua') as die Dawidiese Messias wat deur God opdrag gegee is om die ganse Israel van hulle sondes te red (sōzō); óf hulle maak hierdie Iessous ('Josua') dood en laat hulle afstammelinge mede-verantwoordelik hou vir sy bloed (Matt 27:25). Diegene wat getrou bly aan die 'wet van die Messias', naamlik die 'evangelie van die koninkryk van die hemel', sal gedurende die hele tydspan van die mensheid se geskiedenis in die teenwoordigheid van God-met-ons (Matt 28:16-20) leef.

\section{Hiperteks as 'n kommunikasiestrategie op 'n abstrakte vlak}

As deel van ons besinning oor die 'stemme' waaruit Matteus se 'ensiklopedie' bestaan, is dit nodig dat ons op die teks se bedoelde geaddresseerdes (die Erstleser) fokus. Eksegete dateer en lokaliseer Matteus gewoonlik as ' $n$ diskoers wat in Antiogië ontstaan het voor die einde van die eerste eeu $\mathrm{nC}$ - soos Douglas R.A. Hare (1993:2) Antiogië bedoel wanneer hy sê: 'where he wrote for a church that contained Christian Jews but that was already largely Gentile Christian in composition.' Verskillende moontlike scenario's van kontekste waarbinne die 'eerste lesers' die teks kon gelees of gehoor het, is al voorgestel. Sodanige leesscenario kan ook as 'n tipe hiperteks beskou word, nie in die konkrete sin van die woord nie, maar op 'n abstrakte vlak.

Vir talle eksegete van 'n vorige generasie ${ }^{3}$ het die konsep Heilsgeschichte ('heilsgeskiedenis') 'n hiperteks daargestel wat selfs op 'n meer abstrakte vlak lê as om Matteus in die die konteks van die eerste-eeuse Antiogië te lees (kyk byvoorbeeld Hagner 2003:193-208; vgl. Carter 2000a:14, 17-29, 36-43; 2001: 9-53; 2005:143). Dit wil voorkom asof Conzelmann (1960:34) se teorie van die 'heilshistoriese' benadering tot die Evangelie van Lukas hierdie Matteus-navorsers, wat binne die raamwerk van 'n 'ouer' redaksioneel-kritiese paradigma gewerk het, ${ }^{4}$ beïnvloed het. Volgens hierdie teorie word heilsgeskiedenis in drie tydperke verdeel (kyk Howell 1990:59-77), wat duidelik onderskei kan word as die era van Israel, die era van Jesus en die era van die kerk.

Myns insiens het 'heilsgeskeidenis' (Heilsgeschichte) as 'n tipe leesstrategie gedien om Matteus te interpreteer vanuit Paulus se perspektief (of eerder: vanuit 'n Lutherse perspektief) van 'n indikatiewe-imperatiewe verhouding. Met hierdie eksegetiese strategie is die paradoks tussen die sogenaamde 'partikuliere' en die 'universele' agtergrond van Matteus ${ }^{5}$ probeer verduidelik.

(vootnota 2 gaan voort...)

kennis te neem dat die 'biblical Joseph's relationship with his brothers emerges as that part of the story which is most similar to Josephus' own life' (vgl Jos, JA ii, 353) (kyk Maren Niehoff se werk, The figure

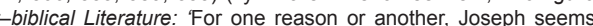
to represent for each narrator a certain Idealtyp' [Niehoff 1992:106]). Vir moontlike Christelike interpolasies in die Testamente van die Twaalf Patriarge, kyk veral De Jonge (1975:96-110); en ten opsigte van Josef en Asenat, kyk Price (1997). Anders as De Jonge sal Hollander (1981:10) argumenteer dat die Testamente beslis nie 'n 'Christelike komposisie' is nie. Alhoewel ek grootliks met Hollander saamstem, beteken dit nie dat ek enigsins enige Christelike interpolasie ontken nie. Die verwysing in die Testament van Josef na die 'lam van God' gebore uit ' $n$ maagd en wat 'die sonde van die wêreld wegneem' is in alle waarskynlikheid so 'n interpolasie. Hierdie argumente is die onderwerp van komplekse debatte rakende intra intra-kanie resultaat van redaksion datering van dokumente, die 'clustering' van 'kanoniese' literatuurgroepe en die lokaliteite van hierdie dokumente se gehore en dokumentkorpusse ensovoorts.

3.Eksegete van ' $n$ vorige generasie wat voorstaanders van die 'heilshistoriese' benadering was, is onder andere G. Barth (1961), W. Trilling (1964), G. Strecker (1966), R. Walker (1967), J.D. Kingsbury (1973) en H. Frankemölle (1974). Vanuit ' $n$ teologiese perspektief kan aangevoer word dat hierdie benadering tot ' $n$ mindere mate gefokus was op die karakters in Matteus se diskoers as wat dit geïnteresseerd was in die 'kerk' se verhouding tot God en dat dit vrae gestel het oor ' $n$ spanning tussen 'genade en wet', 'oordeel en vergiffenis', en 'geloof en werke'.

4. Hierdie siening het tot sekere verskille onder teoloë aanleiding gegee, maar daar was konsensus daaromtrent onder teoloë soos G. Strecker (1962), W. Trilling (1964) en R. Walker (1967).

5.Strecker $(1962: 45-49,184-88)$ het geglo dat die uitstel van die paroesie die be- 
Alhoewel beide Strecker (1963) en Walker (1967) deur Conzelmann se studie van Lukas se heilsgeskiedenis beïnvloed is, verskil hulle ten opsigte van die fyner detail. Hulle is dit egter eens dat drie fases in Matteus se heilsgeskiedenis onderskei kan word: die voorgeskiedenis van die Messias (beginnende met Abraham), die geskiedenis van Israel se opdrag (insluitend die bediening van Johannes die Doper as die voorganger van die Messias en met Jesus as die sentrale punt) en die geskiedenis van die heidensending (beginnende met Jesus se kruisiging en opstanding en wat tot die dag van God se finale oordeel strek).

Die heilsgeskiedenisbenadering het egter nie die breë groep van Matteus-navorsers oortuig nie. Volgens hierdie benadering word die geskiedenis van Israel met dié van die kerk vervang. So iets gebeur egter nie in Matteus nie (kyk onder andere Sim 1995: 243-243, 44; 1998:243-43, 46; teenoor Luz 2005: 631). Die wending (wat 'tyd' betref) wat ingetree het, beteken nie 'n skeiding tussen die geskiedenis van Israel en dié van die kerk nie. Die geskiedenis van Jesus en die kerk is onafskeidelik deel van Israel se geskiedenis - in Matteus (1:1) se eie woorde: biblos geneseds Iēsou Christou (kyk Van Aarde 1998:16-28).

'n Ander hiperteks op 'n hoogs abstrakte vlak, is die sogenaamde eindtyd apokaliptiese benadering. ${ }^{6}$ Dit is in hierdie verband belangrik om in ag te neem dat apokaliptisisme sonder ' $\mathrm{n}$ geloof in die opstanding uit die dood, ondenkbaar is. Ek vind dit daarom ook hoogs waarskynlik dat Ernst Käsemann ([1960] 1969:82-107) ${ }^{7}$ se standpunt reg is dat dit die reaksie op Jesus se dood deur die vroegste Jesus-groep in Jerusalem was wat tot die oorsprong van die 'Christelike teologie' aanleiding gegee het (kyk Van Aarde 1999:795-826; 2002:118-142; 2004:711-738). Ek is egter nie oortuig deur Sim $(1989,1996,1998,2002)$ - om my eie terminologie wat aan die begin van hierdie artikel uiteengesit is te gebruik - dat Matteus se hiperteks getuig van 'n konflik tussen charismatiese volgelinge van Jesus, wat geweier het om te hou by die Mosaïese of Talmoediese wet en die apokalipties-georiënteerde volgelinge van Jesus. Matteus en Paulus verteenwoordig, in die woorde van Mohrlang (1984:131) 'two examples of how the early Christian community perceived Jesus to provide a new basis for ethical living'.

langrikste kwessie by die verstaan van die heilsgeskiedeniskonsep in Matteus is Matteus het, om die waarheid te sê, 'n lewe van Jesus daargestel wat van eskatologiese relevansie is met betrekking tot die voorgeskrewe weg van regverdigheid in die heilsgeskiedenis. Volgens Meier (1975:203-215) was dit Matteus se bedoeling om ' $n$ heilshistoriese skema met nasionale (Israel) en geografiese afbakening daar te stel (Matt 10:5-6: 15.24, 28). Daarteenoor het Hummel (1966.25) daarop daar te stel (Matt 10.5-6, 15.24, 28). Daarteenoor het Hummel (1966:25) daarop gewys dat die belangrikste punt dit is dat Jesus redding vir heidene verkondig he (5005 $15.21-28)$. Dit is daarom dat Meus 'consciously draws up a schema of salvation history which widens the geographica and national restictions of Jesus public ministry into a universal mission (mission to the Gentile) after the death resurrection.' Strecker (1966:87) het dieselfde siening gehuldig as Kingsbury (1973:470), wat onder Matteus-navorsers bekend staan vi sy sogenaamde heilshistoriese beklemtoning wat op die sogenaamde 'tydsformule' in Matteus 3:1 en 24:19, 22, 29 gebaseer is (Kingsbury 1973:470). Volgens Kingsbury is daar ' $n$ eksklusief eskatalogiese konnotasie wat verwys na 'that period of time which precedes the consummation of the age and the return of Jesus, Son of Man' aan hierdie tydformule verbonde. In een van sy ander studies stel Kingsbury (1977:83-84) dit soos volg: '... Matthew, as 11:13 indicates, sees the law and the prophets, the entire [Old Testament], as 'prophesying', as pointing forward, to the events that mark the eschatological age of salvation.

6.Proponente van hierdie benadering sluit L. Cope (1989), D. Hagner (1985:53-82; 1994:49-71) en D.C. Sim (1993: 3-12; 1996) in. Sim (1998) verskil egter van teoloë (1904:49-71) soos Hagner (1993, 1995) oor kwessies soos of Matteus se gemeenskap al reeds met formation 'kerk' al voltooi was. Vir Matteus en die 'eerste lesers' van sy geloofsgemeenksap was 'the separation of Israel into a majority hostile to Jesus and a minority consisting of disciples of Jesus is definitive. At the very latest since the Jewish War they were no longer living in the land of Israel but in Gentile Syria. In Syria, their own mission was the proclamation of the commandments of Christ to the Gentiles under the signature of the universal mission command of the risen Lord' (Luz 2005:631).

7.Wat 'apokaliptisisme' betref, wys Käsemann daarop dat Matteus brokkies bevat wat nie in die ander evangelies voorkom nie en wat ons help om die Christelike oorsprong te rekonstrueer. By wyse van aanhalings uit die Hebreeuse Bybel (bv Matt $7: 22-23 ; 23: 8-10 ; 5: 19)$, dui hy aan dat daar 'n geskiedenis agter die tekste skuil waarin daar duidelike spanning is wat uit 'teologiese' verskille met betrekking tot Jesus se dood voortspruit. Dit is egter moeilik om ' $n$ histories-kritiese rekonstruksie van hierdie 'reaksie' (kyk Käsemann 1969:82) te maak, omdat daar slegs fragmente oor die eerste Jesus-groep in Handelinge tot ons beskikking is. As gevolg van al die oor die eerste Jesus-groep in Handelinge tot ons beskikking is. As gevolg van al die
verskillende brokstukkies van die mosaïek, het ons 'n duidelike beeld van presies verskillende brokstukkies van die mosaïe
wat hierdie vroegste 'teologie' behels het.
In dieselfde trant verwys Wim Weren (1979) in sy doktorale proefskrif oor Matteus se eskatologie na Matteus se de-apokaliptiserende tendens (Entgeschichtlichung der Eschatolologie). ${ }^{8}$ Deur weg te doen met die tipiese dualisme wat in apokaliptisisme tussen 'n huidige wanhopige tyd en 'n naderende tyd van verlossing voorkom, het Matteus die aandag hergefokus op die etiek van die versorging van die armstes onder die armes (vgl Matt 25:45), na wie Weren in die titel van sy boek as 'de broeders van de Mensenzoon' verwys. Hulle was die objek van beide Jesus se opdrag en dié van die dissipels (kyk Van Aarde 2007; vgl Weren 1979:188). ${ }^{9}$ Weren (1979:190) kom dus tot die slotsom dat die eindtyd in Matteus as 'n deurlopende teenswoordige perspektief funksioneer waarvolgens die lesers uitgedaag word om nie met hulle onmiddellike, konkrete omstandighede vrede te maak nie, maar om dit eerder deur konkrete aksie die hoof te bied. Eskatologiese uitsprake is dus etiese appèlle. ${ }^{10}$ Dit kom eksplisiet in die Onse Vader voor in die versoek dat God se koninkryk mag kom, gevolg deur die frase 'op aarde soos in die hemel' (vgl Weren 1979: 190). Volgens Weren (1979:188) kan Matteus egter nie as ' $n$ 'apocalypticist' gereken word nie. Die rede daarvoor is dat Matteus nie sy lesers sien as mense wie se etiek op passiwiteit sou dui omdat hulle slegs op die eindtyd wag wanneer hierdie onregverdige aiōn deur God se oordeelsdaad van vergelding (waardeur die regverdiges gewreek sal word) vervang sal word nie.

'n Beduidende siening wat besonder betekenisvol is by die beskouing van Matteus se hiperteks op so 'n abstrakte vlak, is een wat onlangs deur veral Warren Carter (2000b, 2001, 2005, $2007,2008)$ voorgestaan word. ${ }^{11}$ Carter verwerp die gedagte dat verlossing bloot ' $n$ 'spirituele' aangeleentheid is en nie ook 'n sosiale een nie. In die eerste-eeuse Mediterreense kultuur het politiek en ekonomie 'n integrale deel van kultiese lewe gevorm. Die 'heilshistoriese' benadering is 'n sprekende voorbeeld van 'n anachronistiese interpretasie wat neig om die vertikale en horisontale dimensies van verlossing van mekaar te skei Volgens Carter was Jesus (as Josua die verlosser) 'n politieke figuur wat mense van politieke onderdrukking bevry het. Om aan te voer dat Jesus nie 'n politieke Messias was soos wat van die seun van Dawid verwag is nie, het 'n cliché geword. Carter beklemtoon dat Jesus, as basileus (='koning') die alternatief vir die keiser as verlosser van die volk was. Hy gee toe dat die leiers van Israel Jesus se opponente was, maar slegs insoverre dit hulle medewerking met Rome betref.

\section{DIE ENSIKLOPEDIE VAN SŌZŌ IN MATTEUS}

Gesien vanuit die perspektief van Jonathan Culler (2001:103) se insig, naamlik dat intertekstualiteit betrekking het op 'n werk se 'participation in the discursive space of culture', vind die uitbeelding van die Israelse elite wat met Rome geheul het, weerklank in Matteus se narratief. Hierdie 'discursive space of culture' vorm 'n 'ensiklopedie' in terme waarvan Matteus se oortuiging dat Jesus verlos, begryp behoort te word.

In Matteus se storie staan die protagonis Jesus as basileus $\left(={ }^{\prime}\right.$ koning $\left.^{\prime}\right)$ teenoor die keiser. Die kontras is geleë in die wyse hoe Jesus gered het teenoor hoe die keiser as 'verlosser' sōtēr /sōzō opgetree het. Jesus se benadering was dié van 'n herder

8.Weren (1979:188 nota 16, 236) verwys onder andere na die werk van Sand (1972-3).

. In my artikel 'Jesus' mission to all of Israel emplotted in Matthew's story' (Van Aarde 2007:416-436), het ek geargumenteer dat alhoewel die 'menigte' en die 'heidene' 2007:416-436), het ek geargumenteer dat alhoewel die 'menigte' en die 'heidene'
nie die dieselfde karakterrolle in Matteus se plot vervul nie, beide groepe gesamentlik as die objek van Jesus se missie en dié van die dissipels in die post-Pase periode dien. Hierdie siening betwis die argument dat daar ' $n$ diskontinuïteit tussen die 'Israelse menigte' as objek van Jesus se opdrag en die heidene as die objek van die dissipels se sending op post-Pase vlak is. Die sending waarna in beide Matteus 10 en Matteus 28:16-20 verwys word, sinspeel myns insiens op die opdrag aan Jesus se twaalf dissipels met betrekking tot die 'verlore skape van Israel'.

10 ... in de redactie van Mattheüs kan worden aangemerkt, dat hij eschatologische uitspraken verbind met concrete appèls' (Weren 1979:190).

11.Kyk ook The Gospel of Matthew in its Roman Imperial context, onder redaksie van John Riches \& David C. Sim (2005). 
wat vir sy skape omgee, terwyl die keiser die mense van wie hy lojaliteit geëis het, uitgebuit het. Daar was geen genade (eleos / dikaiosunēe nie. Jesus, die hoofkarakter in die narratief, is deur Romeinse owerhede op tipies Romeinse teregstellingswyse doodgemaak.

Jesus het 'God se ryk' (basileia) verkondig. Aangesien die wêreld in die eerste eeu deur die Romeinse Ryk oorheers is, sou die betekenis van die woord basileia op hierdie Ryk dui. Die basileia van God sou die Romeinse Ryk direk opponeer. Matteus beeld die leiers van Israel as bondgenote van Rome uit. God het die leiers van Israel as bondgenote van Rome gestraf deur, ironies genoeg, Rome as instrument te gebruik om Jerusalem te verwoes (Matt 22:7). ${ }^{12}$

Deur hoofsaaklik Markus as sy hipoteks en $\mathrm{Q}$ as 'n interteks te gebruik, het Matteus - as 'n metateks tot Markus - die Jesusstorie teen die agtergrond van 'n bepaalde hiperteks, naamlik die Josua-storie oorvertel. Die konteks van hierdie hiperteks kan as 'n proses en 'n geestelike ingesteldheid beskryf word. Die proses was dié van die sogenaamde skeiding tussen sinagoge en die kerk wat na die verwoesting van die tempel in Jerusalem in $70 \mathrm{nC}$ ingetree het. Die geestelike ingesteldheid was dié van 'n apokaliptisisme wat Matteus van Markus en ('n latere weergawe) van Q (kyk Kloppenborg 2000:256) oorgeneem het. Die apokaliptiese verwagting was dat hierdie wêreld in die finale ryk van God omskep sou word. Volgens een bepaalde profetiese tradisie (die sogenaamde idee van die nasies se pelgrimstog na die Sionberg) ${ }_{13}^{13}$ sou die nuwe era aanbreek wanneer Israel se messias as die Seun van die Mens in Jerusalem openbaar sou word en wat daartoe aanleiding sou gee dat die nasies na Jerusalem sal kom om by die verenigde Israel aan te sluit.

Verskeie eksegete ${ }^{14}$ is oortuig dat Matteus met die Jesus-groep in Jerusalem gekonformeer het. Die 'twaalf apostels' verteenwoordig vir Matteus die herstelde Israel. Volgens die evangelis (kyk Matt 19:28), verkry die twaalfdissipels as'geneesde genesers' geregtigheid (kri/nontej) vir die twaalf stamme van Israel (vgl Horsley 1987:201-207) teen die agtergrond van die profetiese idee van 'n pelgirmstog van 'alle nasies' na die 'nuwe Jerusalem'. Die ganse Israel (panta ta ethnē) vorm die ekklēsia (die 'Christelike' kultus) teenoor die sunagōgēe (die tempelkultus).

Anders as die opinie van ander Matteus-navorsers waarna ek vroeër in die artikel verwys het, is ek van mening dat Matteus se herkoms nie in Antiogië gesoek behoort te word nie, maar wel van iewers in die noorde van Galilea en die suide van Sirië ná $70 \mathrm{nC}$ (vgl die uitdrukking 'Galilea van die heidene' in Matt 4:15). In hierdie streek het konflik geheers tussen die skrifgeleerde (grammateus) Matteus en dorpskrifgeleerdes, wat besig was om die eerste fase van 'n Fariseïstiese rabbinaat te vestig. ${ }^{15}$ Die Evangelie van Matteus kon dus - soos Q (vgl

12.In drie hoofstukke oorheers die instrumente van Rome die toneel: die kliëntkonings Herodes die Grote (Matt 2) en sy seun Herodes Antipas (Matt 14), en die Romeinse goewerneur, Pontius Pilatus (Matt 27). By twee geleenthede gee Jesus opdrag aan goewerneur, Pontus Pllatus (Matt 27). By twee geleenthede gee Jesus opdrag aan sy visie dat God groter is as die mag van Rome (Matt 17:24-27; Matt 22:15-22).

13.Bv, Matt 8:11 e v /Luk 13:28 e v; Sag 2:11; Targum op Jes 2:2b; 2 Esra 13:49; 2 Barug 72:3-6

14.Kyk, byvoorbeeld Käsemann ([1960] 1969:83, 86) en Hengel (1995:155, 158, $67,181)$. Hengel $(1995: 83,86)$ stel dit soos volg: 'In early Christianity analogous ideas are supposed in Matt. 19:28 = Luke 22:30; 1 Cor. 6:2f. and Rev. 20:4ff. More significant was the parallel tradition that the son of man/messiah as representative and saviour of the true people of God is given the authority to judge; this is documented in the Similitudes of 1 Enoch and in particular in the teaching of Jesus and in earliest Christianity including Matt. 25:31ff. ... [A]pparently dependent upon the language of the Similitudes .. [Matthew - 19:28; 25:31] . twice mentioned the language of the Sitiludes ... .Mathew - 19.28, 25.31] ... twice mentioned that the Son of Man 'sits on the throne of his glory' and the twelve disciples as the followers of Jesus become his college of associate judges ....' Aldus Henge (1995:173), 'in particular the motif of sessio ad dexteram was material common o early Christian congregations, whether in Corinth, Antioch or Rome, and in my opinion demonstrates incontestably that they go back to earliest Jesus group in Jerusalem congregation.

15.Kyk ook Schlatter ([1933] 1963), wat van mening is dat daardie Matteus waarskynlik ' $n$ 'etiese rigoris' was en ' $n$ verteenwoordiger van die vroegste 'Christelike rabbinaat'.
Horsley 1999:145-46, 193-94) - gesien word as die produk van skrifgeleerde-aktiwiteit in die konteks van die heropbou van dorpe na die Judese-Romeinse oorlog en die verwoesting van die tempel in Jerusalem. Sterk aanduiding bestaan dat hierdie dorpsgemeenskappe gesukkel het om die verlies van Jerusalem en die tempel te verwerk.

Aangesien die 'stad van God' nie meer bestaan het nie, moes hulle God se teenwoordigheid in die omgewing van dorpsgemeenskappe vind. ${ }^{16}$ Hier het konflik geheers tussen twee groepe skrifgeleerdes: die volgelinge van Jesus, wat hom as messias erken het en ander Israeliete wat die tradisionele siening van die messias gehandhaaf het.

Die konflik het rondom die interpretasie van die Tora gesentreer: Jesus kon gesien word as die nuwe Moses wat die Tora vervul het, teenoor 'n tradisionele Mosaïese siening soos wat dit deur die tempelkultus gereguleer is. Te midde van Romeinse uitbuiting was skrifgeleerdes betrokke by die heropbou van die dorpslewe. Die skrifgeleerdes in die sinagoges het 'n probleem daarmee gehad dat Jesus as die 'geneser- seun van Dawid' beskou is. Hulle kon nie aanvaar dat hy Israel se nuwe Moses was nie. Hulle kon nie verstaan dat Jesus 'die tempel kon vervang' nie, siende dat Jesus weg gedoen het met die reinheidsregulasies, soos wat geblyk het uit sy genesingsdaad op die Sabbatdag (Matt 12:1-32).

By wyse van 'n parateks verwys Matteus implisiet na die bedoelde skrywer van sy diskoers as 'n skrifgeleerde (grammateus) wat 'n dissipel van die koninkryk van die hemel (Matt 13:52) geword het en wie se agtergrond Jerusalem en die leierskonflik daar was. Die outeur dra 'bagasie' met hom saam wat bestaan het uit oortuigings wat die vroegste Jesus-groep in Jerusalem gehuldig het voordat Jakobus (Jesus se broer) begin het om hierdie kultiese groep te oorheers.

'n Aantal kenmerke, soos wat vervolgens bespreek sal word, onthul Matteus se sienswyse en het 'n invloed op die 'ensiklopediese eggo's' agter die Josua-storie as Matteus se hiperteks.

\section{DIE TERM SŌZŌ EN DIE ‘INTERTEKSTE’ VAN HIERDIE BEGRIP}

Aan die begin van die evangelie (Matt 1:21c), word die naam 'Jesus' gekoppel aan Jesus se roeping as die verlosser wat die volk van Israel van hulle sondes (hamartiōn) sal verlos (sōsei). Die aanwesigheid van die woord biblos in Matteus 1:21 - wat hier die rol van ' $n$ titelopskrif vervul - is dus een van Matteus se mees kenmerkende paratekste. Vir Matteus is die naam 'Jesus' nie sommer 'n gewone benaming nie. In Markus het mense soos Bartimeus en die twee mans wat deur bose geeste gevul was, hom 'Jesus' genoem (Mark 1:24, 5:7; 10:47), maar nie in Matteus (Matt 8:29; 20:30) nie. In Matteus, het die twee geneesde blindes, omdat hulle Jesus as die Dawidiese Messias erken het, gesien waaroor God se redding werklik gaan (Matt 20:30) en die besetenes in Gadara het in die openbaar verklaar dat God Israel deur Jesus, God se seun (Matt 8:29), genees.

Matteus se beskouing van Jesus se geboorte is analoog aan Moses se wondergeboorte in Josefus se Antiquitates (2.205-206, 210-211,215-216) en Pseudo-Filo se Liber Antiquitatum Biblicarum

16.Die Jesus-beweging in Galilea en die werk van die vroeë post-70 nC rabbi's, na wie Horsley (1996:181-84) verwys as die 'earlier scribes and sages', kan gesien word as ' $n$ 'revitalization of village communities'. Nadat die tempel verwoes is, het Fariseër-skrifgeleerdes hulleself in plekke soos Jamnia (in Judea), Galilea en Sirië geherorganiseer. Daar het hulle gepoog om die ou waardesisteme van die tempel, veral regulasies met betrekking tot die hiërargie in die samelewing en die reinheidsideologie van die tempel in dorpshuishoudings te dupliseer. 'n Soortgelyke reinheidsideol aktiwiteit on 'n herkellig, word ook onder die Jesus-groepe gevind. Die waardesisteem wat hulle geïmplimentee het, was gebaseer skrifgeleerdes en skrifgeleerdes in die geledere van Jesus se volgeling aanleiding gegee. 
(9:1-10), wat tussen 70 en $100 \mathrm{nC}$ dateer. Die uitdrukking om Israel te 'bevry' het in die 'latere' Rabbynse tradisie (in Meg 14.2 byvoorbeeld) betrekking op Miriam se verwysing na haar moeder Jogabed wat geboorte aan die toekomstige verlosser (Moses) sou skenk ('My moeder sal 'n seun [Moses] baar wat sal bevry.'] Hierdie uitdrukking sinspeel op die woord 'Josua' in Num 3:17. Ander dokumente verwys ook na hierdie Moses-tradisie en vir Matteus dien dit soms eksplisiet en by ander geleenthede weer implisiet as intertekste (vgl. onder andere Bloch 1954:210-285; [1955] 1978:94-227; Crossan 1968:119-135; 1986:18-27; 2003:663-691).

Die werkwoordstam van die Hebreeuse woord is jashac. Hierdie woord se hiphil word in 'n aantal Ou-Testamentiese tekste (Rigt 6:36; 1 Sam 10:19; 11:13; 14:39; Sag 8:7; Ps 7:11; 17:7) as 'n substantiewe deelwoord, moshiah, gebruik. Op hierdie plekke beteken die substantiewe deelwoord 'helper' (=verlosser). Hierdie betekenis van moshia herinner aan die naam van Moses en is 'n woordspeling (paronomasia) op die deelwoord messiah / mašiah.

Messias het die technicus terminus vir die 'gesalfde seun van Dawid' (of Dawid se seun) as die koning oor die ganse Israel (2 Sam 5:1-3) geword. In Ps 118:25 is daar 'n voorbeeld van so 'n woordspeling tussen moshia (=Moses) en messias (=seun van Dawid) wat in die Griekse uitdrukking 'hoshiah na' voorkom. In Matteus 21:9 siteer die evangelis onder andere Psalm 118:25-26: 'Hosanna vir die seun van David.

Wat bedoel word om Jesus 'geneser-messias' te noem, word duidelik wanneer ander passasies waarin die woord sōzō in Matteus voorkom, bestudeer word.

Die 'ensiklopediese eggo's' vir die stilmaak van die storm in Matteus 8:18-27 is die antieke Nabye Oosterse idee dat die see (veral 'n storm ter see) die magte van chaos en die bose teenoor God simboliseer. Hierdie episode in Matteus is gesetel in Psalm 107:23-30 as interteks. Deur aan te toon dat Jesus mag oor die see het, doen Jesus wat God volgens Psalms 74:13-14 en 89:10-12 doen. Hierdie Psalms is paratekste wat in die interteks opgeneem is. Die paratekste is apokalipties van aard en verwys na die seemonsters Leviatan (Ps 74:14) en Rahab (Ps 89:10-11), wat simbolies is van die bose magte wat oorwin is wanneer God se koninkryk in sy volheid kom (kyk 2 Barug 29:4 as nog 'n parateks).

Matteus se weergawe van die verweefde storie van die aristokratiese raadslid se dogter (wat nie soos in Markus 'n leier van 'n sinagoge is nie) en van die vrou met bloedvloeiing in Matteus 9:18-26 is 'paradigmaties' van die eksklusiwiteit van die 'ou' Israel en die inklusiwiteit van die Matteus-gemeenskap as die 'nuwe' Israel. ${ }^{17}$ Matteus as metateks verander Markus se nadruk op menstruele vloeiing na bloeding in die algemeen. In die metateks word die ouderdom van die amptenaar se dogter (12 jaar) weggelaat. Op die ouderdom van twaalf sou 'n jong vrou in die bepaalde kultuur as seksueel volwasse en gereed vir die huwelik beskou word. Volgens Levitikus 15:19-30 - 'n parateks in Markus as Matteus se hipoteks - is 'n vrou wat menstrueer, onrein en mag nie aangeraak word nie. In Markus word Jesus deur 'n vrou wat menstrueer, aangeraak. In Matteus as metateks gaan dit nie oor menstruasie nie en neem die vrou ook nie die inisiatief nie. Sy is egter net soos ander onrein mense 'n persoon in eie reg wat Jesus se liefde ontvang. Herstel van lewe word beklemtoon deur die drievoudige gebruik van sōzō in 9:20-22 in Matteus se 'kommentaar' op Markus.

Matteus se idee van inklusiwiteit word ook deur die woord 'al die' / 'die hele' / 'die ganse' (holos / holē), wat dikwels voorkom, verwoord. Matteus se begrip van outentieke lewe

17. Hierdie stories is 'much more than examples of faith'. Volgens Elaine Wainwright (1991.214), is dit 'stories of a woman and a young girl oppressed by religious, social and human boundaries and of Jesus as the one who reaches out across these boundaries offering new expectations for life and wholeness behels integriteit/kongruensie (teleiotēs): 'n 'completeness ... which unites everything in complete harmony' (Newman 1971: 80). Dit is kongruensie wat tot uitdrukking bring dat innerlike lewe met uiterlike gedrag ooreenstem. Skynheiligheid verbloem kongruensie (Matt 23:13-36). Volgens Matteus (23:2) sit die skynheiliges op Moses se 'sitplek' en hou van die beste plekke in die sinagoges (Matt 23:6). Hulle verteenwoordig die Israelse elite wat met die Romeinse imperiale mag (Matt 10:17) geheul het: die sunedria (plaaslike Israelse dorpsrade) en die sunagōgai (vergaderings van sinagoge-skrifgeleerdes) wat kragte met die égemōn (Romeinse goewerneurs) en die basileus (Romeinse kliëntkonings) saamgesmee het. Volharding teenoor die mag van hierdie wêreldmag van nasies (tois ethnesin) sal tot bevryding (ho de hupomeinas eis telos houtos sōthēsetai - Matt 10:22) lei.

In Matteus 14:24 red Jesus die dissipels se skuit wat deur die golwe van die see geteister is. In hoofstukke 14 en 16 kom die dubbelsinnige rol van Petrus, die dissipels se woordvoerder, na vore. In Matteus 14:28-33 reik Jesus sy hand na die twyfelende Petrus, 'n 'kleingelowige' (Matt 14:30-31), wat uitroep: 'Here, red my' (kurie, sōson me). Nadat Jesus Petrus berispe het, het hy die dissipels daaraan herinner dat 'wie sy lewe wil red/ behou (sōsai) dit sal verloor, maar wie sy lewe ter wille van my verloor, sal dit terugkry' (Matt 16:25).

Wanneer Matteus in Hoofstuk 19 vertel van die dissipels se verbasing toe hulle besef het wat Jesus met kongruensie (ei theleis teleios einai) bedoel, naamlik dat die rykes hulle besittings moes verkoop en die geld vir die gemarginaliseerde armes (dos tois ptōchois - Matt 19:21) gee, wou hulle weet, 'Wie kan dan gered word (sōthēnai)' (Matt 19:25)?

Die verbygangers wat Jesus tydens die kruisiging belaster het, het verwys na Jesus se woorde oor die vernietiging van die tempel (Matt 27:39-40). In die lig van die herinnering aan Jesus se woorde oor die vernietiging van die tempel, sy 'profesie' oor die verdrukking van 'alle nasies' en sy opmerking oor die liefde (agape) wat sal verkoel (Matt 24:1-14), herinner Matteus sy lesers aan wat die profeet Daniël gesê het oor die oorwinning van die Seun van die Mens (Matt 24:15-28,29-31) oor die Romeinse Ryk wat God gebruik het om Jerusalem te vernietig (Matt 24:27-28). God sal die 'uitverkorenes bymekaar (...) maak uit die vier windstreke, van elke uithoek van die aarde af' (Matt 24:31).

In Matteus 24:22 sinspeel die evangelis op 'n ander tipiese apokaliptiese idee wat ook in 2 Barug 83:1(vgl Josephus, Ant 19:13) (kyk Harrington 1991:337) tot uitdrukking kom. Hierdie interteks verwys na God se redding te midde van droefheid: 'En as daardie dae nie verkort was nie, sou geen mens gered $(e s \bar{t} t h \bar{e})$ wees nie; maar ter wille van die uitverkorenes sal daardie dae verkort word. Maar hulle wat volhard, sal tot die einde gered word (sōthēsetai) (Matt 24:13) (my parafrase van die oorspronklike).

\section{‘N OOP-EINDE}

Die einde van hierdie artikel eggo die manier waarop Matteus sy eie diskoers 'eindig', dit wil sê dit is 'n oop einde - net soos wat die idee van intertekstualiteit self ook is: 'Every text is a locus of intersections, overlaps, and collisions between other texts. Every text is an intertext, that is, a between-text (inter, 'between'), a paradoxical locus of dislocation, without center and without boundaries' (Beal 2000:128).

Volgens Matteus (24:14), sal die evangelie van die koninkryk (euangelion tēs basileias) 'in die hele (holēe' wêreld verkondig word, sodat al (pasin) die nasies die getuienis kan hoor. Eers dan sal die einde (to telos) kom.' Teen die agtergrond van hulle konflik met die imperiale magte van destyds, laat Matteus sy lesers in God se hande - God wat self besluit oor die voleinding van die wêreld (sunteleia tou aiōnos) (Matt 28:20), sodat die kerk in die uitvoering van die sendingopdrag aan alle mense (panta ta ethne) sal ervaar dat Jesus God-met-ons is, want die volgelinge van Jesus het die koms van die Seun van die Mens gesien. 


\section{LITERATUURVERWYSINGS}

Alkier, S., 2005, 'From text to intertext: Intertextuality as a paradigm for reading Matthew', HTS Teologiese Studies/ Theological Studies 61, 1-18.

Argyle, A.W., 1951-1952, 'The influence of the Testaments of the Twelve Patriarchs upon the New Testament', Exp T 63, 256-58.

Beal, T.K., 2000, 'Intertextuality', in A.K.M. Adam (red.), Handbook of postmodern Biblicalinterpretation, pp. 128-130, Chalice Press, St Louis.

Barth, G., 1961, 'Das Gesetzesverständnis des Evangelisten Matthäus', in G. Bornkamm, G. Barth \& H-J. Held, (Hrsg.), Überlieferung und Auslegung im Matthäusevangelium, pp. 54-154, 2. Auflage, Neukirchen Verlag, Neukirchen.

Barthes, R., 1985, 'Texte (théorie du)', in Encyclopaedia Universalis, vol. 17, pp. 996-1000, Seuil, Paris.

Bloch, R., 1954, 'Quelques aspects de la figure de Moïse dans la tradition rabbinique, Cahiers Sioniens 8, 210-285, in $\mathrm{H}$. Cazelles (red.), Moïse, l'homme de l'Alliance, pp. 93-167, Special edition of Cahiers Sioniens, nos. 2-4 of 1954, Desclée, Tournai.

Bloch, R., [1955] 1978, 'Note methodolique pour l'étude de la literature rabbibnique', Recherchesde Science Religieuse 43, 94-227, reprinted 1978 as Methodological Note for the Study of Rabbinic Literature, in W.S. Green (red.), vertl W.S. Green \& W.J. Sullivan, Approaches to Ancient Judaism, 1:Theory and Practice, pp. 51-75, Scholars Press for Brown University, Missoula. (Brown Judaic Studies 1).

Burchard, C., 1965, Untersuchungen zu Joseph und Aseneth: Überlieferung-Ortbestimmung, Mohr, Tübingen, (WUNT 8).

Carter, W., 2000a, Matthew and the margins: A sociopolitical and religious reading, Orbis, Maryknoll.

Carter, W., 2000b, Matthew and Empire: Initial explorations, Trinity Press International, Harrisburg.

Carter, W., 2001, Matthew and Empire: Initial explorations, Trinity Press International, Harrisburg.

Carter, W., 2005, 'Matthean Christology in Roman imperial key: Matthew 1:1', in J. Riches, \& D.C. Sim (reds.), The Gospel of Matthew in its Roman imperial context, pp. 143-165, T \& T Clark, Londen.

Carter, W., 2007, 'Power and identities: The contexts of Matthew's Sermon on the Mount', in D. Fleer \& D. Bland (reds.), Preaching the Sermon on the Mount, pp. 8-33, Chalice Press, St Louis.

Carter, W., 2008, 'Matthew negotiates the Roman Empire', in R.A. Horsley (red.), In the shadow of Empire: Reclaiming the Bible as a history of faithful resistance, pp. 117-136, Westminster John Knox, Louisville.

Chesnutt, R. D., 1996, 'From text to context: The social matrix of Joseph and Aseneth', SBL 1996, Seminar Papers, Scholars Press, Atlanta.

Conzelmann, H., [1958] 1960, The theology of St Luke, vertl G. Buswell, Faber and Faber, Londen.

Cope, O. L., 1989, “To the close of the age': The role of apocalyptic thought in the Gospel of Matthew', in J. Marcus \& M.L. Soards (reds.), Apocalyptic and the New Testament: Essays in honour of J. Louis Martyn, pp. 113-124, Sheffield Academic Press, Sheffield. (JSNTSS 24).

Crossan, J.D., 1968, 'Structure and theology of Mt. 1.18-2.23', Cahiers de Joséphologie 16, 119-135.

Crossan, J.D., 1986, 'From Moses to Jesus: Parallel themes', Bible Review 2(2), 18-27.

Crossan, J.D., 1998, The birth of Christianity: Discovering what happened in the years immediately after the execution of Jesus, HarperSanFrancisco, San Francisco.

Crossan, J.D., 2003, 'Virgin mother or bastard child?', HTS Teologiese Studies/Theological Studies 59(3), 663-691.

Culler, J., [1981] 2001, 'Presupposition and intertextuality', in J. Culler (red), The pursuit of signs: Semiotics, literature, deconstruction, pp. 100-118, augmented edition with new preface, Cornell University Press, Ithaca.

Danow, D.K., 1987, 'Lotman and Uspensky: A perfusion of models', Semiotica 64, 343-357.
De Jonge, M.J., 1975, The Testaments of the Twelve Patriarchs: A study of their text, composition and origin, Gorcum, Assen.

Eco, U., 1984, The role of the reader: Explorations in the semiotics of texts, Indiana University Press, Bloomington (AiS).

Frankemölle, H., 1974, Jahwebund und Kirche Christi: Studien zur Form- und Traditionsgeschichte Des 'Evangeliums' nach Matthäus, Aschendorf, Münster.

Genette, G., 1982, Palimpsestes: La littérature au second degree, Seuil, Parys.

Hagner, D.A., 1984, 'Apocalyptic motifs in the Gospel of Matthew: Continuity and discontinuity', Horizons in Biblical Theology 7, 53-82.

Hagner, D.A., 1994, 'Matthew's eschatology', in T.E. Schmidt \& M. Silva, (reds.), To tell the mystery: Essays on New Testament eschatology in honor of Robert G. Gundry, pp. 49-71, JSOT Press, Sheffield. [JSNT Supplement Series 100.) Reprinted in SBLSP 35 (1996), 163-181].

Hagner, D.A., 1995, 'Matthew: Apostate, reformer, revolutionary?', New Testament Studies 49, 193-208.

Hare, D.R.A., 1993, Matthew: Interpretation, A Bible Commentary for Teaching and Preaching, John Knox, Lousville.

Harrington, D.J., 1991, The Gospel of Matthew, Liturgical Press, Collegeville.

Hatina, T. (red.), 2008, Biblical interpretation in early Christian Gospels, Volume 2: The Gospel of Matthew, Continuum T \& T Clark, Edinburgh.

Hengel, M., 1995, "Sit at my right hand!", in Studies in Early Christology, pp. 119-226, T \& T Clark, Edinburgh.

Hens-Piazza, G., 2000, 'Lyotard', in A.K.M. Adam (red.), Handbook of postmodern Biblical interpretation, pp. 160-166, Chalice, St Louis.

Hillenaar, H., 1982, Roland Barthes: Existentialisme, semiotiek, psychoanalyse, Van Gorcum, Assen.

Hollander, H.W., 1981, Joseph as an ethical model in the Testaments of the Twelve Patriarchs, Brill, Leiden.

Horsley, R.A., 1987, Jesus and the spiral of violence: Popular Jewish resistance in Roman Palestine, Harper \& Row, San Francisco.

Horsley, R.A., (with J. A. Draper) 1999, Whoever hears you hears me: Prophets, performance and tradition in $Q$, Trinity Press International, Harrisburg.

Howell, D.B., 1990, Matthew's inclusive story: A study in the narrative rhetoric of the First Gospel, JSOT, Sheffield.

Hummel, R., 1975, Die Auseinandersetzung zwischen Kirche und Judentum im Matthäusevangelium, Chr. Kaiser Verlag, München.

Käsemann, E., [1960] 1969, 'The beginnings of Christian theology', in New Testament questions of today, pp. 82-107, vertl W.J. Montague, SCM Press, Londen.

Kingsbury, J.D., 1973, 'The structure of Matthew's gospel and his concept of salvation-history', CBQ 35, 451-474.

Kingsbury, J.D., 1974, Matthew: Structure, christology, kingdom, Fortress, Phialdelphia.

Kingsbury, J.D., 1977, Matthew, Fortress Press, Philadelphia.

Kingsbury, J.D., 1986, Matthew as story, Fortress Press, Philadelphia.

Kloppenborg Verbin, J.S., 1999, Excavating Q: The history and setting of the Sayings Gospel, Fortress Press, Minneapolis.

Kristeva, J., 1969, Sémeiotiké: Recherches pour une sémanalyse, Seuil, Parys.

Liszka, J.J., 1996, A general introduction to the semeiotic of Charles Sanders Peirce, Indiana University Press, Bloomington.

Lotman, J.M., 1974, 'Point of view in a text', New Literary History 6, 339-352.

Lyotard, J-F., [1979] 1984, The postmodern condition, vertl G. Bennington and B. Massumi, University of Minnesota Press, Minneapolis.

Lyotard, J-F., 1989, 'Lessons in pragmaticism', vertl D. Macey, in A. Benjamin (red.), The Lyotard reader, pp. 122-154, Basil Blackwell, Oxford.

Luz, U., 2003, Intertextualität im Matthäusevangelium, paper read to the Gospel of Matthew Seminar, Studiorum Novi Testamenti Societas, $57^{\text {th }}$ General Meeting, Bonn, Germany, 29 July-2 August, published as 'Intertexts in the Gospel of Matthew', Harvard Theological Review 97 (2004), 119-137. 
Luz, U., 2005, Matthew 21-28: A commentary, Fortress Press, Minneapolis.

Meier, J.P., 1975, 'Salvation-history in Matthew: In search of a starting point', CBQ 37, 203-215.

Mohrlang, R., 1984, Matthew and Paul: A comparison of ethical perspectives, Cambrige University Press, Cambridge.

Newman, B.M., 1971, A concise Greek-English dictionary of the New Testament, United Bible Societies, Londen.

Niehoff, M., 1992, The figure of Joseph in post-biblical literature Jewish literature, Brill, Leiden.

Peirce, C.S., 1934, Collected papers of Charles Peirce, Volume V, Harvard University Press, Cambridge .

Petersen, N.R., 1980a, 'The composition of Mrk 4:1-8', HThR 73, 185-217.

Petersen, N.R., 1980b, 'Literary criticism for New Testament critics', in R.A. Spencer (red.), Orientation by disorientation: Studies in literary critcism and biblical literary criticism: Presented in honor of William A, Beardslee, pp. 25-50, Pickwick, Pittsburgh.

Philonenko, M., 1968, Joseph et Aseneth: Introduction, texte critique en notes, Brill, Leiden.

Price, R.M., 1997, 'Implied reader response and the evolution of genres: Transitional stages between the ancient novels and Apocryphal Acts', HTS Teologiese Studies/ Theological Studies 53(4), 909-938.

Riches, J. \& Sim, D.C., 2005, The Gospel of Matthew in its Roman imperial context, T \& T Clark, Londen.

Sand, A., 1972-1973, 'Zur Frage nach dem 'Sitz in Leben' der apokalyptischen Texte des Neuen Testaments', New Testament Studies 18, 167-77.

Sim, D.C., 1989, The Gospel of Matthew and Christian Judaism, T \& T Clark, Edinburgh.

Schlatter, A., [1933] 1963, Der Evangelist des Matthäus. Seine Sprache, seine Ziel, seine Selbstbeständigkeit: Eine Kommentar zum ersten Evangelium, 6, Auflage, Calwer Stuttgart.

Sim, D.C., 1993, ,The meaning of paliggenesia in Matthew 19:28', Journal for the Study of the New Testament 50, 3-12.

Sim, D.C., 1995, 'The Gospel of Mattew and the Gentiles', Journal for the Studies of the New Testament 57, 19-48.

Sim, D.C., 1996, Apocalyptic eschatology in the Gosepl of Matthew, Cambridge University Press, Cambridge.

Sim, D.C., 1998, The Gospel of Matthew and Christian Judaism: The history and social setting of the Matthean community, T \& T Clark, Edinburgh.

Sklar, H. W., 1994, 'The fighter of horizons: The story of Joseph as a model for social and spiritual reconciliation', MA thesis, Graduate Theological Union, Berkeley.

Standartinger, A., 1994, From fictional text to socio-historical context: Some considerations from a textcritical perspective on Joseph and Aseneth, in SBL 1996 Seminar Papers, pp. 303-318, Scholars Press, Atlanta.
Standartinger, A., 1996, Das Frauenbild im Judentum der hellenistischen Zeit: Ein Beitrag anhand von 'Joseph E Aseneth', Brill, Leiden. (Arbeiten zur Geschichte des Antiken Judentums und des Urchristentums.)

Strecker, G., 1965, Der Weg der Gerechtigkeit: Untersuchung zur Theologie des Matthäus, 2, Auflage, Vandenhoeck \& Ruprecht, Göttingen.

Trilling, W., 1964, Das wahre Israel: Studien zur Theologie des Matthäus-Evangeliums, 3, Auflage, Kösel, München.

Thiselton, A.C., 2006, 'A retrosepctive reappraisal: Postmodernity, language and hermeneutics', in A.C. Thiselton (red.), Thiselton in hermeneutics: The collected works and new essays of Anthony Thiselton, pp. 663-682, Ashgate Publishing Limited, Aldershot. (Ashgate Contemporary Thinkers on Religion: Collected Works.)

Uspenski, B., 1973, A poetics of composition: The structure of the artistic text and typology of a compositional form, vertl V. Zavarin \& S. Wittig, University of Calfornia Press, Berkeley.

Van Aarde, A.G., 1998, 'Matthew 27:45-53 and the turning of the tide in Israel's history', BTB 28(1), 16-26.

Van Aarde, A.G., 1999, 'The historicity of the circle of the Twelve: All roads lead to Jerusalem', HTS Teologiese Studies/ Theological Studies 55(2\&3), 795-826.

Van Aarde, A.G., 2002, 'Matthew and apocalypticism as the 'mother of Christian theology': Ernst Käsemann revisited', HTS Teologiese Studies/Theological Studies 58(1), 118-142.

Van Aarde, A.G., 2004, 'The earliest Jesus group in Jerusalem', Verbum et Ecclesia 25(2), 711-738.

Van Aarde, A.G., 2005, 'IHSOUS, the Davidic Messiah, as political saviour in Matthew's history', in J.G. Van der Watt (red.), Salvation in the New Testament: Perspectives on soteriology, pp. 7-31, Brill, Leiden (Supplements to Novum Testamentum 121.)

Van Aarde, A.G., 2007, 'Jesus' mission to all of Israel emplotted in Matthew's story', Neotestamentica 41(2), 416-436.

Wainwright, E., 1991, Towards a feminist critical reading of the Gospel according to Matthew, De Gruyter, Berlin. (BZNTW 60).

Walker, R., 1967, Die Heilsgeschichte im ersten Evangelium, Vandenhoeck \& Ruprecht, Göttingen.

Weren, W.J.C., 1979, De broeders van de Mensenzoon: Mt 25, 31-46 als toegang tot de eschatologie van Matteüs, Uitgeverij Ton Bolland, Amsterdam.

Zerbe, G.M., 1992, Non-retaliation in early Jewish and New Testament texts, JSOT Press, Sheffield. 